\title{
IDENTITAS BUDAYA TIMOR DALAM ANTOLOGI CERPEN MENYUDAHI KABAIR KARYA SAYYIDATI HAJAR: KAJIAN STILISTIKA KULTURAL
}

\author{
TIMOR CULTURAL IDENTITY IN THE ANTHOLOGY OF SHORT STORIES \\ MENYUDAHI KABAIR BY SAYYIDATI HAJAR: STUDY OF CULTURAL STYLISTICS
}

\section{Uman Rejo ; Nurul Baiti Rohmah ${ }^{\mathrm{b}}$}

\author{
aUniversitas Timor \\ Jalan Km 09, Kelurahan Sasi, Kota Kefamenanu \\ Kabupaten Timor Tengah Utara, Nusa Tenggara Timur \\ bInstitut Agama Islam Negeri Tulungagung \\ Jalan Mayor Sujadi Timur No. 46 Tulungagung, Jawa Timur \\ umanrejo@unimor.ac.id; nurulbaitirohmah@iain-tulungagung.ac.id
}

\begin{abstract}
(Naskah diterima tanggal 22 Agustus 2020, direvisi terakhir tanggal 26Juni 2021, dan disetujui tanggal 25 Oktober 2021)
\end{abstract}

DOI: https:/ / doi.org/10.26499/wdprw.v49i2.628

\begin{abstract}
This paper aims to explore and describe the Timor cultural identity contained in Sayyidati Hajar's anthology of the short stories, Menyudahi Kabair. This Timor cultural identity is more focused on the use of cultural diction and rhetoric tools contained in the short stories by Sayyidati Hajar. To explore and develop this mission, the literary approach used is a cultural stylistic approach. There are 12 short stories in this anthology, but only 5 short stories are used as the object of study. The method used is a qualitative descriptive method. The results and discussion show that the cultural diction which is used as a marker of Timor cultural identity can be categorized into a cultural one which indicates a nickname or designation, place names, local traditions, commands, actions, sounds or special sounds, names of animals, and designations for a house name. This cultural diction has a cultural meaning related to Timor culture according to Sayyidati Hajar's expression through the short stories she produces. The means of rhetoric as a support for this cultural diction can be seen from various aspects, including in terms of sentence structure, the technique of expression used, the accuracy or appropriateness of the choice of words used, the meaning of the word, the lexical structure, changes in meaning, and whether or not the meaning represented in the short story.
\end{abstract}

Keywords: cultural identity; Timor culture;cultural stylistics

Abstrak
Tulisan ini bertujuan untuk mengeksplorasi dan mendeskripsikan identitas budaya Timor yang terdapat
dalam antologi cerpen Menyudahi Kabair karya Sayyidati Hajar. Identitas budaya Timor tersebut lebih
difokuskan pada penggunaan diksi-diksi kultural dan sarana retorika yang terkandung dalam cerpen
karya Sayyidati Hajar. Untuk mengeksplorasi dan mengembangkan misi tersebut, maka pendekatan
sastra yang digunakan adalah pendekatan stilistika kultural. Ada 12 cerpen yang terdapat dalam antolo-
gi ini, tetapi hanya 5 cerpen yang dijadikan sebagai objek kajian. Metode yang digunakan adalah metode
deskriptif kualitatif. Hasil dan bahasan menunjukkan diksi-diksi kultural yang digunakan sebagai pe-
nanda identitas budaya Timor dapat dikategorikan menjadi diksi kultural yang menunjukkan panggilan
atau sebutan, nama tempat, tradisi lokal setempat, perintah, tindakan, suara atau bunyi-bunyi khusus,
nama binatang, dan sebutan untuk nama rumah. Diksi kultural tersebut memiliki makna kultural yang 
berkaitan dengan kebudayaan Timor sesuai ekspresiSayyidati Hajar melalui cerpen-cerpen yang dihasilkannya. Sarana retorika sebagai pendukung diksi-diksi kultural tersebut dapat dilihat dari berbagai segi, di antaranya segi struktur kalimat, teknik pengungkapan yang digunakan, ketepatan atau kesesuaian pilihan kata yang digunakan, makna kata, struktur leksikal, perubahan makna, dan langsung ti-daknya makna yang direpresentasikan dalam cerpen.

Kata-kata kunci: identitas budaya; budaya Timor; stilistika kultural

\section{Pendahuluan}

Sastra sebagai produk budaya yang bersifat estetis-kreatif menggunakan bahasa sebagai media utama untuk menyampaikan setiap misi yang diembannya. Bahasa sastra berbeda dengan bahasa nonsastra pada umumnya. Bahasa sastra memiliki kekhasan dan nilai rasa tersendiri. Bahasa sastra lebih unik, nyeleneh, aneh, bergantung pada licentia poetica yang dikuasai oleh masing-masing pengarang dalam berekspresi dan memainkan bahasa yang digunakannya dalam setiap karya kreatif yang dihasilkan. Selain bermakna konotatif, bahasa sastra mempunyai potensi yang ekspresif, sugestif, dan polyinterpretable dibanding dengan bahasa nonsastra. Ekspresif artinya bahasa sastra dapat meningkatkan gairah pembaca untuk mengungkapkan isi dan perasaannya, jiwa-nya, serta ide-ide yang ingin disampaikan pengarangnya. Sugestif artinya bahasa sastra dapat digunakan untuk memmengaruhi atau mengajak pembacanya untuk memasuki rea-litas-realitas yang diekspresikan pengarang melalui produk-produk kreatif yang dihasilkan. Polyinterpretable memiliki arti bahwa bahasa sastra memiliki makna yang tidak tunggal, melainkan memiliki multimakna, makna yang dimunculkan lebih dari satu. Itulah kekhasan dan keunikan bahasa sastra sebagai produk budaya yang bersifat kreatif-estetis.

Menyudahi Kabair (2019)merupakan karya sastra yang berbentuk antologi cerita pendek karya Sayyidati Hajar. Antologi cerpen ini merupakan antologi cerpen pertama yang dihasilkan oleh Sayyidati Hajar. Antologi ini tersusun atas 12 cerpen, yang berju- dul "Atois dan Suara-Suara Duka", "Galeri Sepi", "Alaut", "Jessi dan Malam Natal Sebelumnya", "Pengakuan", "Menyudahi Kabair", "Kepala Ayam", "Mengenang Hujan", "Setelah Malam Itu", "Perempuan Cahaya”, "Perempuan yang Menyimpan Surga di Kepalanya", dan "Nete Noebunu". Salah satu cerpen dalam antologi ini pernah dimuat dalam Victory News edisi 27 Januari 2019, yakni cerpen berjudul "Menyudahi Kabair". Dengan tebal buku sebanyak 100 halaman, antologi ini berhasil diterbitkan oleh salah satu penerbit buku ternama yang ada di Kota Kupang Nusa Tenggara Timur bernama IRGCS (Institute of Resource Governance and Social Change).

Dalam biografi singkat pada bagian akhir antologi dikatakan bahwa Sayyidati Hajar merupakan perempuan asli Timor yang lahir di Kefamenanu pada 25 Juli 1990 dengan nama asli Siti Hajar. Ia sekarang menjadi pengajar di kampus Universitas Muhammadiyah Kupang, Nusa Tenggara Timur. Pendidikan tingginya dimulai di Jurusan Pendidikan Bahasa dan Sastra Indonesia (2013) dan Ma-gister Pendidikan Bahasa Indonesia (2016) di Universitas Indraprasta PGRI Jakarta (Unindra). Sebelum menjadi pembina Komunitas Sastra Pondok Aspira, Sayyidati Hajar pernah aktif dalam Komunitas Ranggon Sastra Unindra dan Klub Jurna-listik. Beberapa karya yang dihasilkan di antaranya Fetor Noebunu (2017), Bermain Kelereng (bentuk alih wahana cerpen karya Eduawardus Umbu Kodi, 2018), Perempuan-Perempuan Pesisir (2018), Maria (2018), Perempuan Sebelum Fajar 
(2018), dan Perja-lanan Mencari Ayam (bentuk dari alih wahana cerpen karya Armin Bell, 2019).

Tujuan utama tulisan ini disajikan adalah untuk mengeksplorasi dan mendeskripsikan identitas budaya Timor yang terepresentasikan dalam antologi cerpen Menyudahi Kabair karya Sayyidati Hajar. Representasi identitas budaya Timor tersebut akan difokuskan pada penggunaan diksi-diksi kultural sebagai penanda dan sarana retorika sebagai pendukung narasi yang terdapat dalam karya Sayyidati Hajar ini. Untuk mengeksplorasi dan mengembangkan misi tersebut secara intensif, maka pendekatan sastra yang digunakan adalah pendekatan stilistika kultural.

Menurut Aminuddin (1995), stilistika dalam arena ilmu susastra merupakan studi sastra tentang cara pengarang dalam menggunakan sistem tanda yang sejalan dengan gagasan yang ingin disampaikan dari kompleksitas dan kekayaan unsur pembentuk, yang dijadikan sebagai sasaran kajian hanya pada wujud penggunaan sistem tandanya. Walaupun berfokus pada wujud sistem tanda untuk memperoleh pemahaman tentang ciri penggunaan sistem tanda, bila dihubungkan dengan cara pengarang dalam menyampaikan gagasan, pengkaji perlu juga memahami gambaran objek atau peristiwa teks sastranya, gagasan, serta ideologi yang terkandung dalam teks sastranya. Ratna (2009)menambahkan, stilistika merupakan ilmu tentang gaya, bagaimana segala sesuatu diungkapkan dengan cara tertentu, sehingga tujuan yang dimaksud dapat dicapai secara maksimal. Gaya dalam hal ini dijadikan sebagai sarana yang digunakan pengarang untuk menuangkan apa yang dimaksudkan di dalam sebuah karya sastra. Dalam hal ini, Ratna (2009) menyimpulkan bahwa objek utama kajian stilistika adalah teks atau wacana sastra.
Leech dan Short (2007) membedakan empat ciri formal kebahasaan, yang disebutnya sebagai kategorisasi stilistika, yakni kategori leksikal, kategori gramatikal, bahasa figuratif, serta kohesi dan konteks. Aspekaspek kebahasaan inilah yang menjadi fokus dan objek kajian stilistika secara umum, dengan tujuan utama menjelaskan bagaimana dukungannya untuk mencapai efek keindahan dalam teks sastra yang dikaji. Keraf (2009) menambahkan, sarana penggunaan bahasa itu tidak sekadar penggunaan bahasa untuk mengungkapkan gagasan, tetapi sampai pada bagaimana gaya berbahasa itu menjadi manifestasi kreatif pengarang. Selain itu, penelusuran terhadap gaya kepengarangan juga dapat digunakan sebagai sarana dalam menilai pribadi, watak, dan kemampuan seseorang yang mempergunakan aspek kebahasaan tersebut.

Menurut Nurgiyantoro (2015), stilistika adalah sebuah ilmu yang mengkaji tentang fungsi artistik penggunaan bahasa dalam berbagai konteks. Unsur keindahan sebuah teks memiliki kriteria keindahan yang berbeda bergantung ragam bahasanya, misalnya teks-teks sastra memiliki kriteria keindahan yang tidak sama dengan kriteria keindahan teks-teks ilmiah. Teks-teks yang mengandung unsur budaya tertentu secara kental, sebagaimana yang banyak dijumpai dalam teks-teks kesastraan, tampaknya lebih tepat jika didekati dengan pendekatan stilistika kultural. Hal itu juga sesuai dengan hakikat disiplin stilistika yang berada dalam persinggungan antara kutup linguistik di satu sisi dan kutup seni serta kultural di lain sisi. Penjelasan kata dan ungkapan tertentu yang sarat makna filosofis-budaya dapat secara intensif dieksplorasi dengan menggunakan pendekatan stilistika kultural.

Dengan demikian, melalui pendekatan stilistika kultural beberapa cerpen yang terdapat dalam antologi Menyudahi Kabair karya Sayyidati Hajar dapat dieksplorasi secara 
komprehensif. Potensi akan representasi identitas budaya Timor yang mempunyai muatan filosofis dalam antologi cerpen tersebut dibedah dengan berfokus pada diksidiksi kultural yang terdapat di dalamnya serta pemanfaatan sarana retorika yang diekspresikan oleh pengarang melalui produk kreatif yang dihasilkannya tersebut. Dengan begitu, representasi yang menjadi misi utama dalam tulisan ini dapat tereksplorasi secara gamblang, intensif, estetis, fokus, terarah, dan bahasan yang disajikan menjadi lebih komprehensif, unik, serta lebih menarik.

Untuk mendukung bahasan berkait penanda identitas budaya Timor dalam antologi cerpen karya Sayyidati Hajar ini, digunakanlah paradigma emik-etik untuk mendukung konsep epistemologi yang digunakan dalam pendekatan stilistika kultural. Paradigma etik-emik dalam kajian sosial-budaya pernah digunakan Clifford Geertz dalam The Religion of Java yang selanjutnya dialihbahasakan menjadi buku Abangan Santri dan Priyayi dalam Masyarakat Jawa (1981) oleh Aswab Mahasin. Selain itu, dalam kaitannya dengan budaya Timor, Gregor Neonbasu menganjurkan untuk menggunakan paradigma ini. Hal ini sesuai dengan buku monografinya berjudul Citra Manusia Berbudaya: Sebuah Monografi tentang Timor dalam Perspektif Melanesia (2017). Menurut Neonbasu(2017), setiap peneliti membutuhkan pemikiran abstrak dan teori (etik) namun kajian yang bakal dilakukan hendaknya secara serius berfokus pada konteks kehidupan sosialbudaya yang diteliti (emik). Argumentasi dan ide umum dapat digunakan sebagai pedoman dasar (etik), namun saat akan mengambil sebuah keputusan dan simpulan, kepentingan realitas sosial-budaya termasuk hal yang tidak tampak dari aspek sosialbudaya yang dikaji (emik), haruslah menjadi titik representasinya. Oleh karena itu, pendekatan stilistika kultural dengan menggunakan paradigma etik-emik tersebut dapat menjadi komprehensif untuk mengeskplorasi dan mendeskripsikan beberapa penanda representasi identitas budaya Timor yang terdapat dalam antologi cerpen karya Sayyidati Hajar ini.

\section{Metode}

Tulisan ini disajikan dengan menggunakan metode deskriptif kualitatif. Metode ini sangat efektif dan efisien digunakan karena mampu memberikan pemahaman dan penjelasan yang memadai sehubungan dengan fakta-fakta empirik yang berkaitan dengan identitas budaya Timor yang dibahas. Secara umum, sumber data yang digunakan dibedakan menjadi dua, yakni sumber data primer dan sekunder ((Rejo, 2021)(Rohmah, 2017)). Sumber data primer berupa antologi cerpen berjudul Menyudahi Kabair (2019) karya Sayyidati Hajar. Antologi cerpen ini diterbitkan kali pertama pada Mei 2019 dengan tebal 100 halaman oleh penerbit IRGCS (Institute of Resource Governance and Social Change). Sebuah penerbit yang berlokasikan di Kota Kupang, Nusa Tenggara Timur. Selanjutnya, sumber data sekunder berupa data penunjang fokus utama dalam bahasan tulisan ini. Data penunjang tersebut berupa buku-buku yang membahas tentang identitas budaya Timor, laporan hasil penelitian lainnya, serta artikel-artikel ilmiah baik berbentuk artikel jurnal ataupun artikel yang terpublikasikan di berbagai media. Oleh karena metode yang digunakan deskriptif kualitatif, maka data yang digunakan berbentuk katakata, kalimat, dan kutipan-kutipan yang terdapat dalam sumber data ((Rejo, 2020); (Rejo \& Rohmah, 2020); (Rohmah \& Rejo, 2020)).

Antologi ini tersusun atas dua belas cerpen, tetapi lima cerpen yang dijadikan sebagai objek kajian yakni cerpen yang berjudul "Atois dan Suara-Suara Duka", "Alaut", "Kepala Ayam", "Nete Noebunu", dan "Pengakuan". Untuk teknik pengumpulan data yang digunakan adalah teknik pustaka, 
teknik catat, dan teknik interview atau wawancara. Teknik pustaka (library) merupakan salah satu teknik pengumpulan data dan informasi yang dilakukan dengan menelaah sumber-sumber tertulis. Sumber-sumber tertulis tersebut seperti yang telah disampaikan pada bagian sebelumnya, tepatnya berada pada bagian sumber data, baik yang sumber data primer maupun sekunder, baik yang sumber data tercetak maupun yang terdigitalkan. Teknik selanjutnya adalah teknik catat. Teknik catat merupakan teknik pengumpulan data yang dilakukan dengan cara mencatat semua data yang telah digunakan saat pengumpulan data menggunakan teknik pustaka. Teknik interview atau wawancara digunakan untuk mendapatkan data berkait dengan beberapa data tentang budaya Timor yang terekspresikan dalam setiap cerpen karya Sayyidati Hajar melalui diksi-diksi kulturalnya dan sarana retorika yang digunakan. Teknik ini melibatkan dua pihak, yakni penulis cerpen dan beberapa orang asli Timor yang memahami budaya Timor yang disinggung dalam cerpen yang dibahas. Untuk mendapatkan keabsahan data dilakukan triangulasi data ((Rejo, 2021); (Rejo \& Rohmah, 2020); (Rohmah \& Rejo, 2020)).

Dalam analisis data, teknik yang digunakan adalah teknik analisis isi atau content analysis. Teknik analisis ini sangat sesuai karena dapat memberikan pemahaman dan penjelasan terhadap isi yang dianalisis ((Rejo, 2021); (Rejo \& Rohmah, 2020); (Rohmah \& Rejo, 2020)). Cara menggunakan teknik ini dengan menguraikan fokus bahasan yang didiskusikan dalam tulisan ini secara objektif, sistematik, detil, dan mendalam. Hal ini dilakukan dengan misi agar identitas budaya Timor dalam antologi cerpen yang ditekankan dapat tersampaikan secara optimal. Pertama, menganalisis beberapa penanda representasi identitas budaya Timor dalam cerpen yang dikaji, dengan berfokus pada diksi-diksi kultural ketimoran yang digunakan. Kedua, menganalisis sarana retorika dalam cerpen yang digunakan pengarang sebagai pendukung dalam merepresentasikan identitas budaya Timor, dengan berfokus pada beberapa segi yang bisa dijadikan sebagai acuan. Segisegi tersebut yang membantu memberikan eksplorasi lebih lanjut pada bagian kedua ini. Setelah menggunakan teknik analisis isi, maka langkah selanjutnya adalah menyampaikan hasil dan bahasannya dalam bentuk artikel jurnal, yang kemudian dipublikasikan dalam jurnal ini dengan mengikuti gaya selingkung yang disediakan oleh tim redaksi melalui lamannya.

\section{Hasil dan Pembahasan}

\subsection{Diksi-Diksi Kultural sebagai Penanda Identitas Budaya Timor}

Sebagai identitas budaya Timor yang terdapat dalam karya sastra, penggunaan diksidiksi kultural sangat dibutuhkan. Penggunaan bahasa-bahasa tempatan tersebut menunjukkan bahwa kearifan lokal yang dimiliki oleh masyarakat suku tersebut masih digunakan sampai sekarang. Setiap tempatanmemiliki diksi-diksi yang berbeda satu sama lain dengan interpretasi diksi yang berbeda pula, sehingga interpretasi akan pengetahuan lokal secara intensif sangat dibutuhkan untuk memahami diksi-diksi tersebut. Ini dapat dikatakan pula sebagai strategi simbolik yang digunakan pengarang untuk menunjukkan identitas dirinya sebagai orang Timor. Strategi ini pula dapat menjadi ciri khas pengarang dalam berekspresi melalui narasi-narasi kreatif yang dihasilkannya.

Diksi-diksi kultural yang digunakan dalam antologi cerpen karya Sayyidati Hajar ini dapat dikategorikan menjadi beberapa hal. Ada diksi kultural yang menunjukkan panggilan atau sebutan, nama tempat, tradisi lokal setempat, perintah, tindakan, suara atau bunyi-bunyi khusus, nama binatang, dan sebutan untuk nama rumah. Pengategorian diksi-diksi kultural tersebut banyak dijumpai 
dalam setiap cerpen yang terdapat dalam antologi ini dengan penempatan makna masing-masing sesuai dengan penggunaannya. Sayyidati Hajar sebagai penulis antologi cerpen sangatlah piawai menggunakan diksidiksi kultural tersebut. Hal ini menunjukkan bahwa budaya Timor masih melekat dalam dirinya sehingga bahasa-bahasa lokal tersebut masih digunakan dalam karya sastra yang dihasilkannya. Meskipun ia sendiri telah menempuh pendidikan tingginya di luar Pulau Timor yakni Jakarta. Jakarta sebagai kota metropolitan dan tempat tujuan pendidikan tertingginya tidak menjadikan Sayyidati Hajar lupa akan jati dirinya sebagai salah satu orang Timor. Ini menjadi salah satu kelebihan positif yang dimiliki oleh Sayyidati Hajar sebagai penulis karya sastra.

Dari dua belas cerpen yang terdapat dalam antologi ini, ada lima cerpen yang dibahas diksi-diksi kulturalnya. Hal ini disebabkan karena diksi-diksi kulturalnya lebih dominan digunakan dalam limacerpen tersebut. Lima cerpen tersebut di antaranya cerpen berjudul "Atois dan Suara-Suara Duka", "Kepala Ayam", "Pengakuan”, "Alaut”, dan cerpen berjudul "Nete Noebunu". Dalam cerpen "Atois dan Suara-Suara Duka", banyak ditemukan beberapa diksi kultural sebagai penanda identitas budaya Timor. Diksi-diksi kultural tersebut di antaranya ena, ainooh, pah, Mapua', ama, 'taka, dan bnak. Diksi ena dalam cerpen ini digunakan sebanyak delapan kali. Dalam bahasa Dawan Amanuban, diksi ena digunakan untuk menyebut ibu. Hal ini tampak sekali saat penyebutan ena Fanu. Dalam cerpen ini, tokoh ena Fanu digambarkan sebagai perempuan yang berprofesi sebagai tukang urut. Salukh (2019)mengatakan bahasa Dawan merupakan salah satu bahasa lokal di Nusa Tenggara Timur yang paling banyak penuturnya. Secara historiografi, penutur bahasa lokal ini mencapai 600.000 penutur. Bahasa lokal ini memiliki dialek dan logat yang berbeda anta- ra satu subsuku dengan subsuku yang lain, khususnya pada suku Dawan. Subsuku bahasa lokal yang ada di Pulau Timor ini dapat diklasifikasikan menjadi tiga, yakni subsuku yang berada di Timor Tengah Selatan (yakni Amanuban, Amanatun, dan Mallo), subsuku yang berada di Timor Tengah Utara (yakni Miomafo, Biboki, dan Insana), dan subsuku yang berada di Kota dan Kabupaten Kupang (yakni Kopas, Timaus, Amfoang, Sonba'i, dan Nairasis) termasuk subsuku yang berada di Oecusse, Timor Leste (Ambeno). Dengan demikian, dapat disimpulkan bahasa Dawan inilah yang paling banyak digunakan sebagai penanda identitas budaya ketimoran oleh Sayyidati Hajar dalam setiap cerpennya ini. Dengan demikian interpretasi terhadap diksidiksi kultural yang digunakan dalam cerpen ini mengacu pada pemaknaan lokal terhadap bahasa kultural yang bersifat tempatan tersebut.

Diksi kultural berikutnya adalah diksi ainooh. Dalam catatan kaki antologi ini, dikatakan ainooh merupakan diksi lokal yang berasal dari bahasa Dawan. Diksi ini memiliki makna 'aduh'. Diksi ini digunakan untuk mempertegas kata-kata yang mengikutinya. Untuk lebih jelasnya, perhatikan data berikut: "Anak itu mulai tersengal-sengal. Tangisnya melengking tinggi di udara, menembus rimbunan ranting pohon asam dan pohon kelapa yang menjulang. "Sedikit lagi e ... Ainooh ... sedikit lagi," suara ibunya mengusap-usap kepala anaknya" (Hajar, 2019).

Selanjutnya, diksi kultural sebagai penanda identitas budaya Timor berikutnya adalah Mapua'. Dalam kebudayaan Timor, terdapat tradisi yang diberi namaМapua'. Tradisi ini oleh masyarakat Timor di Kabupaten Timor Tengah Selatan sudah menjadi tradisi yang dilakukan secara turun-temurun. Tradisi ini berisikan kegiatan saling bertukar sirih pinang sebagai sebuah sapaan keakraban dan saling menghormati ketika bertemu antara satu orang dengan orang lain. Untuk 
lebih jelasnya, perhatikan data berikut: "Selamat, Pah." Seorang utusan dari desa sebelah mengucap selamat sambil membungkukkan badan. Tempat sirih pinang langsung disuguhkan tak lama setelah tuan rumah menyilakan duduk. Mereka mapua' sebelum utusan itu menyampaikan berita yang membuat kaget seisi rumah" (Hajar, 2019). Sabon (2019) mengatakan sirih pinang telah menjadi simbol masyarakat adat Pulau Timor. Ketika bertamu di rumah-rumah atau berjumpa dengan siapa saja, yang disuguhkan pertama adalah sirih dan pinang. Sirih pinang telah menjadi tata pergaulan dan tata nilai kemasyarakatan. Saat upacara adat, seperti pernikahan, kelahiran, kematian, penyembuhan, sirih dan pinang menjadi simbol tertinggi penghargaan pada tamu yang hadir.

Sebagai penanda identitas budaya Timor berikutnya adalah penggunaan diksi lokal pah. Dalam catatan kaki antologi ini, dikatakan bahwa pah merupakan diksi lokal dalam bahasa Dawan yang memiliki makna 'iya'. Diksi pah ini memiliki kesamaan makna dengan diksi dalam bahasa Jawa yakni diksi $d a-$ lem. Untuk lebih jelasnya, perhatikan data berikut: "Selamat, Pah." Seorang utusan dari desa sebelah mengucap selamat sambil membungkukkan badan. Tempat sirih pinang langsung disuguhkan tak lama setelah tuan rumah menyilakan duduk" (Hajar, 2019). Diksi kultural berikutnya adalah ama. Dalam bahasa Dawan Amanuban, diksi ama merupakan diksi lokal bahasa Timor yang digunakan untuk sebutan 'bapak'. Dalam cerpen "Atois dan Suara-Suara Duka", diksi lokal ini ditemukan sebanyak dua. Artinya, pengarang menggunakan diksi lokal ini sebanyak dua kali. Untuk lebih jelasnya, perhatikan data berikut.

"Ama, bagaimana?" Akhirnya istrinya angkat bicara.

Suaminya tak merespon. Ia masih tenggelam dalam pikirannya sendiri. Lelaki itu baru sadar setelah pembawa berita itu pamit.

"Terima kasih, su datang kasih tahu," Suara laki-laki itu seperti tersenggal di leher ketika mengantar si pembawa berita ke depan pintu.

"Ama, kita masih ada satu kain baru," sambil menunjukkan kain itu. "Saya juga sudah isi bose 5 kilo dalam 'taka. Semua sudah siap. Mari kita jalan sudah," ajak istrinya" (Hajar, 2019).

Diksi kultural berikutnya adalah 'taka. Dalam catatan kaki antologi ini, masyarakat Timor mengenal diksi lokal 'taka. Diksi lokal ini digambarkan berbentuk wadah anyaman yang terbuat dari daun lontar yang tersusun dari sebuah wadah berbentuk silinder yang digunakan untuk menyimpan beras atau jagung, dan sebuah tutupan yang tersusun seperti tangga. Untuk lebih jelasnya, perhatikan data berikut: "ama, kita masih ada satu kain baru," sambil menunjukkan kain itu. "Saya juga sudah isi bose 5 kilo dalam 'taka. Semua sudah siap. Mari kita jalan sudah," ajak istrinya. (...) Perempuan-perempuan yang menyunggi 'taka, para lelaki menarik kambing dan memikul beras di bahu. Mereka berjalan dalam satu baris" (Hajar, 2019).

Selanjutnya, diksi kultural yang terdapat dalam cerpen "Atois dan Suara-Suara Duka" adalah bnak. Bnak dalam perspektif masyarakat Timor, diartikan sebagai bawaan yang berupa uang, kain, selendang, atau sejenisnya yang diberikan ketika melayat di rumah duka. Hal ini se-perti yang disampaikan dalam data berikut: "Perempuan-perempuan yang menyunggi 'taka, para lelaki menarik kambing dan memikul beras di bahu. Mereka berjalan dalam satu baris. Rombongan itu mirip pengibar bendera tujuhbelasan. Langkahlangkah takzim mengikuti pe-rempuan pembawa bnak. Sebuah bingkisan kematian. Kain, selendang tenun, dan amplop putih terbungkus rapi di sana" (Hajar, 2019). 
Dalam cerpen "Alaut", ditemukan pula beberapa diksi kultural sebagai identitas budaya Timor. Diksi-diksi kultural tersebut di antaranya ena, bife alaut, suanggi, ama, alaut, $k e u$, leu', dan $b e^{\prime}$. Penggunaan diksi ena dalam cerpen ini ditemukan sebanyak lima belas kali. Diksi tersebut digunakan untuk sebutan ena Lake. Dalam bahasa Dawan dengan dialek Amanuban, diksi ena tersebut digunakan sebagai sebutan untuk ibu. Dengan demikian, diketahui maksud penggunaan diksi tersebut adalah untuk menyebut ibu yang bernama Lake dalam cerpen berjudul "Alaut" ini. Dalam kaitannya dengan ena ini, masyarakat Timor mengenal adanya tradisi Sei. Tradisi ini biasa dilakukan oleh masyarakat Timor Tengah Selatan. Tradisi Sei bagi masyarakat Timor merupakan kebiasaan masyarakat setempat untuk menghangatkan seorang ibu dengan asap di dalam rumah adat selama 40 hari oleh seorang dukun atau seorang yang dipercayai mempunyai pengalaman merawat ibu melahirkan. Dinarasikan bahwa, setelah seorang ibu selesai melahirkan, ibu dan bayinya harus duduk dan tidur di atas tempat tidur yang di bawah kolong tempat tidur itu terdapat bara api. Bara api ini harus tetap menyala selama 40 hari. Untuk itu sang suami harus menyediakan kayu bakar yang nantinya dipergunakan sebagai bara agar api tetap selalu menyala dan mengeluarkan asap. Cara pengasapan ini oleh masyarakat setempat biasa disebut Sei. Tujuan dari tradisi ini, agar badan dari ibu dan bayi cepat kuat (Soerachman dan Wiryawan, 2013).

Berkaitan dengan tradisi Sei ini, Dhave(2015) mengenalkan adanya tradisi Neno Boha dalam masyarakat Timor. Tradisi ini diperuntukkan untuk ibu setelah melahirkan selama 40 hari. Selama masa nifas tersebut, seorang ibu dilarang keluar dari rumah bulat, yakni rumah adat Timor, begitu pula dengan bayinya. Setiap hari ibu dan bayi harus tinggal di rumah bulat, dan hanya boleh dijenguk oleh kerabat terdekatnya saja. Menurut Dhave (2015), ibu tersebut tidak hanya tinggal di rumah bulat, tetapi harus menjalani ritual yang sangat tidak lazim bagi dunia medis modern saat ini. Ibu setiap hari akan dikompres dengan air panas yang diletakkan pada kain adat Timor. Tujuan pengompresannya untuk memperlancar peredaran darah. Prosesnya ini dinamakan Tatobi. Selama habis melahirkan, ibu juga harus menjalani ritual Peanggan, yakni mengasapi tubuh ibu dan bayi. Perapian dibuat tepat dibawah tempat tidur, lalu ibu dan bayi berada di atasnya. Pengasapan ini dilakukan hampir setiap hari dan harus dijalani selama 40 hari. Tradisi ini seperti disebutkan di depan, dinamakan tradisi Sei. Tradisi ketiga, ibu hanya diperbolehkan mengonsumsi jagung bose. Jagung bose merupakan jagung lokal yang tumbuh di Pulau Timor. Jagung ini menjadi satu-satunya asupan makanan bagi ibu, dan ibu kepada bayinya melalui air susu ibu. Selama mengonsumsi jagung bose, tidak boleh dicampur dengan jenis makanan lain (Dhave, 2015).

Penanda identitas budaya ketimoran berikutnya adalah diksi lokal bife alaut. Diksi lokal ini memiliki keterkaitan dengan diksi suanggi dan alaut. Dalam bahasa Timor, alaut dan suanggi itu memiliki kesamaan, yakni sebutan untuk seseorang yang diyakini memiliki ilmu "hitam" yang berada di wilayah Amanuban kabupaten Timor Tengah Selatan. Selanjutnya, bife alaut merupakan sebutan untuk perempuan yang memiliki suanggi atau perempuan penganut ilmu hitam. Menurut Djaman (2018), ilmu suanggi merupakan salah satu ilmu hitam yang telah melegenda dari ilmu hitam di kawasan Indonesia timur. Bagi masyarakat timur, ilmu ini merupakan ilmu yang paling tinggi di wilayahnya. Orang yang mengamalkan ilmu ini dipastikan akan berubah menjadi sosok makhluk yang mengerihkan, menakutkan, dan menyeramkan. Mitosnya, suanggi merupakan 
sebuah roh jahat yang gemar merasuki tubuh seseorang yang suka menjalani ilmu hitam. Orang yang dirasuki roh suanggi otomatis akan memiliki ilmu hitam suanggi yang bakal mengubah jati diri seseorang menjadi buruk. Orang yang mengamalkannya, akan memiliki kekuatan atau kemampuan santet yang hebat, dan sering membuat teror dengan mengirimkan berbagai penyakit ke sebuah desa yang dibencinya.

Diksi berikutnya adalah keu. Diksi kultural ini dalam bahasa masyarakat Timor dimaknai sebagai teriakan yang dikeluarkan para alaut ketika mendekati mangsanya. Diksi lokal selanjutnya adalah leu'. Diksi ini semacam ilmu sihir yang bisa membuat mereka terbang atau berubah wujud. Selanjutnya, diksi lokal yang menjadi identitas budaya Timor dalam cerpen "Alaut" adalah diksi be'. Dalam bahasa Dawan Amanuban, diksi lokal $b e^{\prime}$ ini digunakan sebagai sebutan untuk Nenek oleh masyarakat Timor. Untuk lebih jelasnya, perhatikan data berikut:

"Keu ... keu ... keu ..." Suara itu seperti datang mendekat ke tempat mereka. Suara keu, suara khas alaut itu, terdengar berulang-ulang, makin keras, dan semakin mendekati rumah Kepala Desa. Ruang pertemuan he-ning sesaat. Mereka saling melirik. Pikiran mereka tertuju satu titik, alaut ada di luar. Sosok alaut dipercaya selalu telanjang, bergelantung di dahan pohon, dan mampu terbang seperti kelelawar. Terkadang, bahkan dapat berubah wujud menjadi binatang. Begitu aksi para alaut. Konon mereka punya leu', semacam ilmu sihir yang membuat mereka bisa terbang dan berubah wujud" (Hajar, 2019).

Dalam wikipedia (2020)disebutkan keberadaan Suanggi di Nusa Tenggara Timur digambarkan berwujud nenek cantik yang menyimpan sangat banyak kedengkian kepada warganya. Nenek cantik yang diceritakan ini hidup pada tahun 1896 di sebuah kampung di Nangaroro, kabupaten Nagekeo, ini akhirnya ingin melampiaskan kedengkiannya terhadap seorang bapak yang pulang dari memancing dan berhasil mendapatkan banyak ikan. Hingga suatu saat, sang nenek datang dan menyembah sebuah pohon besar selama 40 hari. Setelah itu, sang nenek mendengar sebuah bisikan untuk segera pulang ke rumah dan mempraktikkan ilmu hitam yang diperolehnya. Namun, ketika mempraktikkan ilmu hitamnya tersebut, sang nenek akhirnya tewas dan arwahnya gentayangan mencari mangsa. Hal ini berbeda dengan keberadaan suanggi di Halmahera Utara dan Maluku Utara. Di daerah ini, suanggi dikenal me-miliki wujud sebagai seorang perempuan cantik dan mengincar laki-laki hidung belang untuk berhubungan intim. Setelah itu, barulah suanggi menyerang dan memakan alat kelamin laki-laki itu dengan lahapnya. Di Papua, suanggi dikenal dengan nama-nama yang berbeda, seperti di Yaben Barat-Papua menyebutnya dengan "Nyata" dan di Yaben Utara-Papua menyebutnya dengan "Hinata". Beberapa daerah di kabupaten Yaben-Papua, yakni Poom, Ansus, Woy, dan Marau, masih banyak yang takut untuk mendatangi daerah tersebut, karena ilmu suanggi masih kental dimiliki oleh warga setempat.

Dalam cerpen "Kepala Ayam", banyak ditemukan beberapa diksi kultural sebagai penanda identitas budaya Timor. Diksi-diksi kultural tersebut di antaranya bebak, ume khu$b u, b a ' i$, dan 'futu. Dalam bahasa Timor, diksi bebak dalam cerpen ini bermakna pelepah pohon gewang yang di-keringkan kemudian digunakan untuk membuat dinding. Diksi berikutnya adalah ume khubu. Bagi masyarakat Timor, ume khubu merupakan rumah tradisional suku Dawan yang berada di Kabupaten Timor Tengah Selatan. Rumah ini berbentuk bulat. Untuk lebih jelasnya, perhatikan data berikut.

“Batang kasuari berbunga api. Asap mengembang. Arang merah saling 
menggigit dalam bara tungku lalu jatuh perlahan menyisakan bunyi patah-patah. Bau bulu ayam terbakar menyusup keluar melewati alang-alang dan dinding bebak. Bercampur bersama udara bebas, singgah kepada pemilik mata yang kini duduk menghadap ume khubu. Salah seorang anak saya telah merengek sejak pisau bapak-nya menembus leher ayam" (Hajar 2019).

Berkaitan dengan bebak dan ume khubu, Silab dkk. (1997) mengatakan bahwa rumah tradisional masyarakat Dawan atau Atoni Timor memiliki bentuk bulat (khubu). Oleh sebagian orang, rumah yang berbentuk itu ada yang menyebut sebagai ume 'suba, maksudnya rumah yang atapnya mencapai atau mendekati permukaan tanah dengan pintu yang rendah. Untuk memasuki rumah tersebut, orang harus mengambil sikap menunduk atau merangkak agar mudah melewati pintunya. Jika diperhatikan dari atapnya yang mencapai tanah, terdapat sebagian masyarakat yang menyebut rumah ini dengan sebutan ume 'tetnain, maksudnya rumah yang atapnya yang mencapai tanah sehingga tampak seperti tempurung yang ditelungkupkan pada permukaan tanah. Bentuk rumah tradisional ini memiliki ukuran yang sangat bervariasi bergantung pada keinginan dan kebutuhan pemiliknya.

Berkaitan dengan posisi ume khubu, menurut Silab dkk. (1997) masyarakat Dawan atau Atoni Timor memiliki pandangan tentang arah mata angin, sampai kepada pintu lumbung atau lopo. Sebelah Utara dinamakan taes bifa atau laut wanita, maes'e lalan atau jalan garam, dan ada yang menyebutnya aobe lalan atau jalan kapur sirih. Arah ini memiliki makna sumber atau asal-usul barang kebutuhan hidup manusia. Sebelah Selatan dinamakan laut pria, maskulin atau jantan (tasi Atoni). Berbicara tentang arah ini selalu dihubungkan dengan kekuatan gaib yang keras, kasar, bencana, dan ketidakberuntungan. Se- belah Timur merupakan tempat matahari terbit, awal murah/arah datangnya sukusuku bangsa memulai Pulau Timor, awal mula kehidupan dan harapan baru, sumber keberuntungan. Selanjutnya, sebelah Barat merupakan tempat terbenamnya matahari, lambang kematian, akhir dari terang, dan tujuan akhir hidup manusia.

Berkaitan dengan bahan-bahan untuk bangunan rumah (ume khubu) atau lumbung (lopo), Silab, dkk. (1997)membedakannya menjadi enam. Pertama, tiang-tiang (ni), terdiri dari kayu-kayu yang kuat dan pada umumnya kayu teras. Kedua, usuk-usuk (suaf) terdiri dari kayu-kayu lurus yang mudah dilenturkan seperti cemara, dsb. Ketiga, balok-balok penyangga loteng (su'if) yakni kayu bulat atau dapat dibentuk seperti balok. Keempat, kayu penyangga loteng (nonof) terdiri dari kayu-kayu yang lurus. Kelima, atap tefis/tefse yang terbuat dari rumput atau alang-alang (humusu) dan seringkali daun gewang (tuinno'o). Keenam, dinding (nikit) dari bahan pelepah gewang (bebak) atau belahan bamboo (nesat). Bahan-bahan ini juga digunakan untuk pembuatan pelataran loteng (tetu).

Diksi berikutnya yang terdapat dalam cerpen ini sebagai penanda identitas budaya Timor adalah diksi lokal $b a^{\prime} i$. Diksi lokal ini bagi orang Timor digunakan untuk sebutan "kakek". Sebutan ini masih digunakan di beberapa wilayah yang ada di Timor dan sekitarnya. Dalam cerpen "Kepala Ayam" ini, Sayyidati Hajar menggunakannya sebanyak sepuluh kali. Diksi lokal ini digunakan untuk sebutan "kakek" Mollo yang terdapat dalam cerpen tersebut. Diksi berikutnya yang menjadi penanda identitas adalah diksi 'futu. Dalam bahasa Timor, diksi ini diartikan kain putih yang berbentuk seperti selendang dengan memiliki panjang kurang lebih 1,5 meter yang biasanya digunakan sebagai ikat pinggang. Untuk lebih jelasnya, perhatikan data berikut. 
“ [...] Anak-anak duduk mengapit $B a^{\prime} i$ Mollo. Mereka tahu sebentar lagi $B a$ 'iakan melonggarkan 'futu, kain putih panjang yang dijadikan ikat pinggangnya. Selain sebagai ikat pinggang, kain itu merangkap fungsi sebagai dombet. $B a^{\prime} i$ menyimpan banyak pecahan uang logam di situ. Mata anak-anak ber-binar. Satu atau dua keping uang pasti akan mereka dapat dari 'dompet' $B a^{\prime} i$. Bila sedang senang, anak-anak akan dibiarkan sendiri membuka simpul kain tempat di mana uang-uang logam itu diikatnya. [...]" (Hajar, 2019).

Dalam cerpen "Pengakuan", banyak ditemukan beberapa diksi kultural sebagai penanda identitas budaya Timor. Diksi-diksi kultural tersebut di antaranya kete dan nakete. Dalam masyarakat Timor, diksi lokal kete merupakan salah satu bentuk pengakuan dosa yang dilakukan oleh masyarakat suku Dawan. Bentuk kegiatan ini biasanya dilakukan dengan cara berdoa dan mengakui segala kesalahan yang pernah dilakukan, kemudian kegiatan ini dilanjutkan dengan memasukkan uang ke kotak amal yang disediakan di masjid atau gereja. Diksi lokal nakete dimaknai sebagai kata perintah (imperatif) untuk melakukan kete, dengan diberi awalan (prefiks) ' $n a$ ', yang bermakna 'dia', yang sekaligus diksi ini mengandung makna imperatif.

Dalam cerpen "Nete Noebunu", juga ditemukan beberapa diksi kultural sebagai penanda identitas budaya Timor. Diksi-diksi kultural tersebut di antaranya nete, amaf, koa, dan aaueee ... aauooo .... Dalam bahasa Dawan Amanuban, diksi lokal nete dalam cerpen ini bermakna jembatan. Diksi lokal amaf dalam bahasa Dawan Amanuban bermakna sama dengan diksi lokal ama, yang maknanya digunakan sebagai sebutan pada "bapak". Selanjutnya, dalam budaya masyarakat Timor terdapat diksi lokal koa. Dalam bahasa Timor, koa merupakan teriakan yang biasa dilakukan oleh laki-laki Timor yang berada di Amanuban dengan tujuan untuk mengabarkan, memberi informasi, atau memberitahukan sesuatu. Bagi perempuan, biasanya dinamakan ' $h u n u$ '. Sedangkan kata-kata yang digunakan untuk koa oleh laki-laki Timor adalah aaueee .... aauooo .... Diksi-diksi kultural tersebut yang memberi warna lokalitas ketimoran pada cerpen "Nete Noebunu" karya Sayyidati Hajar tersebut. Lokalitas yang menggunakan bahasa tempatan, menjadikan karya sastra yang dihasilkan memiliki kekhasan dan keunikan tersendiri. Identitas budaya Timor yang menjadi sasaran bahasan dalam bagian ini menjadi lebih bermakna karena diimbangi dengan diksi-diksi kultural yang masih kental dengan warna lokalitas ketimorannya. Itulah yang menjadi kelebihan Sayyidati Hajar sebagai penulis kreatif yang piawai merangkai teks narasi dengan diimbangi penggunaan diksi-diksi kultural budaya Timor tersebut.

\subsection{Sarana Retorika Sebagai Pendukung Identitas Budaya Timor}

Untuk mendukung representasi identitas budaya Timor yang diekspresikan oleh Sayyidati Hajar melalui antologi cerpen ini, maka eksistensi representasi tersebut didukung dengan menggunakan sarana retorika yang terdapat dalam masing-masing cerpen. Melalui sarana retorika, cerita yang dikembangkan Sayyidati Hajar menjadi hidup dan penuh totalitas makna yang dipenuhi berbagai pengetahuan berbasis lokalitas. Menurut Keraf (2009), sarana retorika dalam sebuah karya sastra dapat dilihat dari segi struktur kalimat, nada yang digunakan, ketepatan dan kesesuaian diksi atau pilihan kata, penggunaan kata, makna kata yang digunakan, struktur leksikal, berdasarkan langsung tidaknya makna yang didasarkan pada konteks linguistik dan nonlinguistik, dan perubahan makna.

Beberapa sarana retorika tersebut dijadikan sebagai acuan untuk mengetahui repre- 
sentasi identitas budaya Timor yang diekspresikan Sayyidati Hajar melalui cerpencerpen yang telah dibahas dalam bagian sebelumnya. Dalam cerpen berjudul "Atois dan Suara-Suara Duka", "Alaut", "Kepala Ayam", "Pengakuan", dan "Nete Noebunu", Sayyidati Hajar cenderung menggunakan beberapa sarana retorika secara bervariatif. Hal ini tampak secara tersirat dan tersurat digunakan pengarang untuk mendukung diksi-diksi kultural yang menjadi salah satu penanda identitas budaya Timor dalam cerpennya menjadi lebih hidup dan bermakna.

Dilihat dari segi struktur kalimatnya, pengarang cenderung menggunakan teknik repetisi. Teknik ini digunakan pengarang untuk menegaskan interpretasi terhadap diksidiksi kultural yang digunakan. Dalam cerpen "Atois dan Suara-Suara Duka", pengarang menggunakan diksi Ena sebanyak delapan kali. Diksi Ena ini digunakan untuk menegaskan sebutan pada Fanu, menjadi Ena Fanu, yang artinya ibu Fanu. Penggunaan diksi lokal ini juga ada yang berbentuk kalimat langsung dan kalimat tak langsung, maksudnya ada yang dalam bentuk kalimat percakapan dan kalimat pernyataan. Selain itu, di dalam kalimat percakapan juga diikutsertakan beberapa diksi lokal tambahan untuk menguatkan kembali makna pada penggunaan diksi-diksi lokal sebelumnya. Untuk lebih jelasnya, perhatikan salah satu data berikut.

“Ini tasalah su lama. Kalau ada anak kecil itu harus hati-hati. Kalau jatuh cepat bawa datang," Ena Fanu mulai ceramah. "Ini kita harus urut satu atau dua kali," lanjutnya. [...] "Sedikit lagi $e$... Ainooh ... sedikit lagi," suara ibunya mengusapusap kepala anaknya" (Hajar, 2019).

Dengan penggunaan diksi tambahan seperti tasalah su dan sedikit lagi e menjadi identitas budaya Timor yang dijadikan sebagai setting budaya dalam cerpen ini menjadi lebih bermakna. Diksi tersebut akan bernilai rasa beda, jika penggunaannya dilisankan dengan logat dan dialek penutur yang berbeda-beda. Ini yang menjadi salah satu keunikan dari cerpen karya Sayyidati Hajar. Penggunaan teknik repetisi ini tidak hanya ditemukan dalam cerpen ini saja, tetapi dalam empat cerpen yang lain juga ditemukan. Masingmasing diksi lokal yang dipergunakan tersebut dijadikan untuk memperkuat dan mempertegas makna kultural yang terdapat dalam cerpen-cerpen bahasan kajian ini.

Penggunaan teknik repetisi dalam cerpen-cerpen dalam antologi Menyudahi Kabair (2019) ini ada yang disampaikan secara lepizeuksis (diksi ditampilkan secara langsung), tautotes (diksi yang diulang-ulang dalam sebuah struktur kalimat), anafora (diksi yang diulang berada di depan atau awal), epifora (diksi yang diulang berada di akhir), dan mesodiplosis (diksi yang diulang berada di tengah).

Dilihat dari ketepatan atau kesesuaian pilihan kata yang digunakan, pengarang cenderung menggunakan gaya bahasa tak resmi dan gaya bahasa percakapan. Agar tidak cenderung konservatif, maka gaya bahasa standar dengan diimbangi penggunaan diksi-diksi lokal ketimoran menjadikan cerpen yang dihasilkan menjadi renyah dan enak untuk dibaca. Dengan diikutsertakan, penggunaan catatan kaki yang simpel, menjadikan pembaca lebih mudah dalam memahami makna kultural yang ingin disampaikan pengarang melalui cerpennya ini. Dalam memanfaatkan gaya bahasa percakapan, pengarang sangat cerdik dalam memanfaatkan diksi-diksi kekinian, baik diksi yang bersifat lokalitas maupun modern seperti saat ini. Untuk lebih jelasnya, perhatikan data berikut: "Bapak-bapak, tolong kita baomong dengan kepala dingin. Kita semua tau, kalo Ena Leke $s u$ tua. Dia $p u$ umur sa mungkin $s u$ hampir enam puluh tahun. Kalau katong usir, nanti mama tua mau tinggal di mana?" Ama 
Titus, sebagai Kepala Desa, angkat bicara" (Hajar, 2019).

Data dalam gaya bahasa percakapan tersebut yang kaya akan diksi-diksi lokal menjadikan cerita "Alaut" tersebut lebih kuat nilai identitas budaya ketimorannya. Tidak tertutup kemungkinan, gaya bahasa percakapan semacam ini juga ditemukan dalam cerpencerpen Sayyidati Hajar dalam antologi ini. Dalam hal penggunaan kata pada cerpen, pengarang juga membedakan. Ada beberapa diksi lokal dalam antologi cerpen ini yang penulisannya dicetak miring. Secara tersurat, penulisan cetak miring tersebut bertujuan untuk memberi aksen pada diksi-diksi lokal yang khas ketimorannya yang memiliki makna khusus dan tidak bebas dimaknai, berbeda dengan diksi-diksi lokal ketimoran lainnya yang penulisannya tidak dicetak miring karena makna kulturalnya bersifat umum.

Dilihat dari makna kata yang digunakan, pengarang cenderung menggunakan dua kategori makna kata yakni makna kata yang lebih bersifat denotatif dan konotatif. Kedua makna kata ini menghiasi setiap diksi-diksi yang digunakan pengarang dalam bernarasi, baik diksi yang bersifat lokalitas, kultural filosofis, atau diksi yang digunakan dalam percakapan sehari-hari dengan makna yang umum. Untuk mencoba memaknai dua makna kata tersebut, haruslah memiliki pengetahuan lokal tentang ketimoran terlebih dahulu. Apabila pengetahuan lokal tersebut tidak dikuasai, maka akan mengalami fase ambiguitas, yakni fase kebingungan dalam memahami narasi. Pengetahuan lokal yang dibahas tersebut dapat diperoleh dengan memanfaatkan data-data sekunder yang berkaitan dengan pokok bahasan. Dapat dengan cara membaca buku-buku referensi tentang bahasa dan kebudayaan Timor, artikel-artikel ilmiah yang membahas tentang Timor, filmfilm lokal tentang Timor, atau dapat juga dengan berkunjung dan tinggal beberapa ha- ri di Pulau Timor supaya "sedikit paham" akan pengetahuan lokal tentang ketimoran dan kekayaan sosial-budayanya. Hal ini dapat menjadi nilai plus, sehingga fase ambiguitas tersebut tidak mengacaukan pemikiran yang telah serius mencoba memahami dan menikmati karya sastra yang dibaca. Untuk lebih jelasnya, perhatikan salah satu data berikut.

"Aaueee ... aauooo ...!".

Suasana pagi berubah ceria meski gerimis mulai lebih kerap. Koa bersahutsahutan di pinggir sungai. Anak-anak perempuan sigap menurunkan rok merah hatinya ketika turun dari pundak para amaf. Senyum mereka merekah, menyambut keseruan pagi dengan teriakanteriakan menyema-ngati para penyeberang" (Hajar, 2019).

Berdasarkan data tersebut, ada dua diksi lokal dan bunyian yang lokal yang tikannya dicetak miring. Hal ini menunjukkan bahwa pengarang mencoba memanfaatkan diksidiksi lokal tersebut dalam cerpennya guna menjadi penyedap rasa akan kelokalitasan tentang Timor. Apabila pembaca buta akan potensi budaya yang dimiliki masyarakat Timor, maka akan mengalami kesulitan dalam memaknainya. Oleh karena itu, interpretasi dengan diimbangi akan kekayaan pengetahuan lokal budaya yang dijadikan sebagai setting kultural sangat dibutuhkan. Apakah, diksi-diksi tersebut menggunakan makna kata secara grama-tikal atau secara kiasan, secara kontotatif atau denotatif, itu sebuah pilihan dalam bereksplorasi. Sebagai pembaca yang kritis, hal seperti itu bukanlah sebuah beban pengetahuan. Akan tetapi, itu dapat dijadikan sebagai nutrisi pengetahuan yang dapat menambah wawasan khasanah intelektual pembaca yang ahli dan handal.

Dilihat dari struktur leksikal yang digunakan, pengarang banyak memanfaatkan berbagai bentuk relasi semantik yang terdapat dalam diksi-diksi yang telah digunakan. 
Relasi semantik tersebut dapat berbentuk sinonim, antonim, polisemi, hiponim, dan hipernim. Masing-masing bentuk relasi semantik tersebut sa-ling mendukung satu sama lain representasi identitas budaya Timor yang dikembangkan dalam masing-masing cerpen. Tidak semua bentuk relasi ada dalam satu cerpen, melainkan beberapa bentuk tersebut secara keseluruhan merangkum dari lima cerpen yang dijadikan sebagai objek kajian dalam bahasan ini. Bentuk-bentuk ini, secara langsung maupun tidak langsung, secara tersurat atau tersirat, Sayyidati Hajar sebagai pengarang cerpen ti-dak mengetahui keberadaan dan penga-tegoriannya. Hanya saja sebagai pembaca yang kritis, dapat menyimpulkan berbagai kategori bentuk relasi makna yang dimunculkan dalam cerpen tersebut.

Dilihat dari langsung tidaknya makna yang dimunculkan, pengarang dalam antologi cerpen ini banyak menggunakan gaya bahasa yang bersifat retoris dan kiasan. Untuk membedakan kedua gaya bahasa tersebut, perhatikan salah satu data berikut.

"Aroma minyak kelapa dan daun arluda menyengat hidung. Sudah beberapa kali perempuan tua dengan mulut merah merekah itu meminta tambahan minyak. Ia mulai menyapu tubuh anak kecil yang duduk setengah memeluk ibunya. Tak berapa lama semua minyak di botol sempurna pindah ke sekujur badan sebagai pelumas sebelum pijatan inti dimulai. Anak itu mulai menangis. Ibubapaknya sigap menenangkan" (Hajar, 2019).

Berdasarkan data tersebut, dapat dikatakan bahwa pengarang sangat jeli memanfaatkan diksi-diksi sebagai penanda gaya bahasa kiasan. Gaya bahasa kiasan tersebut dalam data tersebut yang paling menonjol banyak yang berbentuk metafora, misalnya menyengat hidung, perempuan tua, merah merekah, menyapu tubuh, dan masih banyak lagi bebe- rapa bentuk metafora yang dapat ditemukan dalam antologi ini. Penggunaan metafora ini tujuan utamanya untuk memberikan aspek dan efek keindahan dalam bahasa yang digunakannya, sehingga tidak memberi kesan sebagaimana bahasa dalam karya ilmiah. Metafora-metafora yang dimunculkan dapat mengalami perubahan makna sesuai dengan konteksnya. Selain metafora, masih banyak lagi piranti-piranti gaya bahasa kiasan yang dapat ditemukan dalam antologi ini. Tidak ada yang mendominasi dalam hal ini berkait dengan piranti gaya bahasa, semua piranti sama-sama mendominasi untuk memberikan nilai-nilai kehidupan dalam cerpen karya Sayyidati Hajar ini. Begitupula dengan gaya bahasa yang bersifat retoris. Sama-sama memiliki misi untuk memberi nilai estetis dalam cerpen-cerpen pada antologi ini. Masingmasing peranti tersebut ada yang berbentuk bandingan, tentangan, tautan, sindiran, penegasan, dan kritikan. Kesemua peranti saling mendukung satu sama lain untuk menguatkan misi yang sama. Misi tersebut yakni mendukung representasi identitas budaya Timor yang terdapat dalam cerpen pada antologi ini.

\section{Simpulan}

Berdasarkan uraian di depan, dapat dikatakan bahwa cerpen-cerpen karya Sayyidati Hajar dalam antologi Menyudahi Kabair (2019) ini banyak merepresentasikan identitas budaya Timor. Ada dua hal penting yang menjadi simpulan dalam tulisan ini. Pertama, pembedahan muatan atau kandungan cerpen dengan pisau bedah pendekatan stilistika kultural menjadikan representasi identitas budaya Timor menjadi lebih hidup, estetis, dan nilai kulturalnya semakin kental dengan sosial-budaya ketimorannya. Hal ini dapat dilihat pada penanda yang digunakan pengarang dalam lima cerpen yang menjadi objek sasaran dalam kajian tulisan ini. 
Diksi-diksi kultural yang digunakan sebagai penanda identitas budaya Timor dapat dikategorikan menjadi diksi kultural yang menunjukkan panggilan atau sebutan, nama tempat, tradisi lokal setempat, perintah, tindakan, suara atau bunyi-bunyi khusus, nama binatang, dan sebutan untuk nama rumah. Diksi kultural tersebut memiliki makna kultural yang berkaitan dengan kebudayaan Timor sesuai ekspresi Sayyidati Hajar melalui cerpen-cerpen yang dihasilkannya. Beberapa diksi kultural yang menjadi penanda representasi tersebut di antaranya penggunaan diksi atois, ena, ainoooh, pah, mapua', 'taka, ama, bose, bnak, suanggi, bife alaut, mau, keu, le, be', bebak, ume khubu, ba'i, 'futu, kete, nakete, amaf, koa, dan seterusnya. Diksi-diksi lokal kultural tersebut dieksplorasi dan dideskripsikan secara kualitatif dengan menggunakan paradigma etik-emik. Hal ini bertujuan untuk menangkap dan menggali identitas budaya Timor yang terdapat dalam masing-masing cerpen karya Sayyidati Hajar melalui antologi Menyudahi Kabair (2019) ini.

Kedua, untuk mendukung representasi identitas budaya Timor dalam antologi cerpen ini, Sayyidati Hajar sebagai pengarang memanfaatkan piranti sarana retorika. Sarana retorika tersebut berada secara implisit dan eksplisit dalam setiap cerpen. Pengarang sangat jeli memanfaatkan peranti-peranti tersebut untuk mendukung setting kultural ketimorannya. Peranti-peranti retorika tersebut dapat dilihat dari beberapa segi, di antaranya segi struktur kalimat, teknik pengungkapan yang digunakan, ketepatan atau kesesuaian pilihan kata yang digunakan, makna kata, struktur leksikal, perubahan makna, dan langsung tidaknya makna yang telah direpresentasikan dalam setiap cerpen yang terdapat dalam antologi Menyudahi Kabair (2019) karya Sayyidati Hajar ini.

\section{Daftar Pustaka}

Aminuddin. 1995. Stilistika: Pengantar Memahami Bahasa dalam Karya Sastra. Semarang: IKIP Semarang Press.

Dhave, Dhanang. 2015. "Neno Boha, Sebuah Tradisi Masa Nifas di Pulau Timor." Www.Kompasiana.Com.

Djaman, Fachri. 2018. "Inilah Lima Ilmu Hitam Paling Menakutkan di Indonesia." Makassar.Terkini.Id.

Gorys Keraf, Dr. 2009. Diksi dan Gaya Bahasa. Jakarta: Gramedia Pustaka Utama.

Hajar, Sayyidati. 2019. Menyudahi Kabair. Kupang: IRGSC.

Leech, Geoffrey N. dan Mick Short. 2007. Style in Fiction: A Linguistic Introduction to English Fictional Prose. Pearson Education.

Neonbasu, Gregor. 2017. Citra Manusia Berbudaya: Sebuah Monografi Tentang Timor dalam Perspektif Melanesia. Jakarta: Antara.

Nurgiyantoro, Burhan. 2015. "Stilistika Kultural (Cultural Stylistics)." Widyaparwa 43(1):1-14.

Ratna, Nyoman Kutha. 2009. Stilistika: Kajian Puitika Bahasa, Sastra, dan Budaya. Yogyakarta: Pustaka Pelajar.

Rejo, Uman. 2020. "Karakteristik Jenis Teks Sastra dalam Mata Pelajaran Bahasa Indonesia Tingkat SMP." Jubindo: Jurnal Ilmu Pendidikan Bahasa dan Sastra Indonesia, 5 (2), 72-87. 
Rejo, Uman dan Nurul Baiti Rohmah. 2020.

"Author's Ideology In Short Story Of Anthology In Sumi dan Gambarnya By Ratna Indraswari Ibrahim: Genetic'Structuralism Study." ISSHE 2020: Proceedings of the First International Seminar Social Science, Humanities and Education, ISSHE 2020, 25 November 2020, Kendari, Southeast Sulawesi, Indonesia, 399. European Alliance for Innovation.

Rejo, Uman. 2021. "Problematika Pembelajaran Sejarah Sastra di Kampus Wilayah Perbatasan Negara Kesatuan Republik Indonesia-Republik Demokratik Timor Leste." Diglosia: Jurnal Kajian Bahasa, Sastra, dan Pengajarannya, 4 (3), 351-364.

Rohmah, Nurul Baiti. 2017. "Simbol dan Akidah Islam: Analisis Semiotik terhadap Serat Darmasonya Karya KPH Suryaningrat." Sabda: Jurnal Kajian Kebudayaan, 10 (2).

Rohmah, Nurul Baiti dan Uman Rejo. 2020. "Representation Of Traditional Buton Events In Fiction Works By Wa Ode Wulan Ratna: a Study Of New Historicism." ISSHE 2020: Proceedings of the First International Seminar Social Science, Humanities and Education, ISSHE 2020, 25 November 2020, Kendari, Southeast Sulawesi, Indonesia, 399. European Alliance for Innovation.

Sabon, Alfius. 2019. “Makan Sirih Pinang, Tradisi Masyarakat Timor." Www.Kompasiana.Com.

Salukh, Neno Anderias. 2019. “Atola: Budaya Berbahasa Amanuban (Dawan-Timor) yang Hampir Punah." Www.Kompasiana.Com.

Silab, W. dkk., 1997." Rumah Tradisional Suku Bangsa Atoni-Timor, Nusa Tenggara Timur. Kupang: Depdikbud Kanwil Nusa Tenggara Timur.

Soerachman, Rachmalina and Yuana Wiryawan. 2013. "Persepsi dan Sikap Masyarakat Desa Di Kabupaten Timor Tengah Selatan tentang Melahirkan." Indonesian Journal of Reproductive Health, 16-22.

Wikipedia, Kontributor. 2020. "Suanggi." Wikipedia. Retrieved September 11, 2020 (https://id.wikipedia.org/wiki/Suangg i). 